\title{
Front Matter: Volume 9925
}

, "Front Matter: Volume 9925," Proc. SPIE 9925, Nanoimaging and Nanospectroscopy IV, 992501 (23 November 2016); doi: 10.1117/12.2258077

SPIE Event: SPIE Nanoscience + Engineering, 2016, San Diego, California, United SPIE. States 


\title{
PROCEEDINGS OF SPIE
}

\section{Nanoimaging and Nanospectroscopy IV}

\author{
Prabhat Verma \\ Alexander Egner \\ Editors
}

28-31 August 2016

San Diego, California, United States

Sponsored and Published by

SPIE 
The papers in this volume were part of the technical conference cited on the cover and title page. Papers were selected and subject to review by the editors and conference program committee. Some conference presentations may not be available for publication. Additional papers and presentation recordings may be available online in the SPIE Digital Library at SPIEDigitallibrary.org.

The papers reflect the work and thoughts of the authors and are published herein as submitted. The publisher is not responsible for the validity of the information or for any outcomes resulting from reliance thereon.

Please use the following format to cite material from these proceedings:

Author(s), "Title of Paper," in Nanoimaging and Nanospectroscopy IV, edited by Prabhat Verma, Alexander Egner, Proceedings of SPIE Vol. 9925 (SPIE, Bellingham, WA, 2016) Six-digit Article CID Number.

ISSN: 0277-786X

ISSN: 1996-786X (electronic)

ISBN: 9781510602410

ISBN: 9781510602427 (electronic)

Published by

SPIE

P.O. Box 10, Bellingham, Washington 98227-0010 USA

Telephone +1 3606763290 (Pacific Time) · Fax +1 3606471445

SPIE.org

Copyright @ 2016, Society of Photo-Optical Instrumentation Engineers.

Copying of material in this book for internal or personal use, or for the internal or personal use of specific clients, beyond the fair use provisions granted by the U.S. Copyright Law is authorized by SPIE subject to payment of copying fees. The Transactional Reporting Service base fee for this volume is $\$ 18.00$ per article (or portion thereof), which should be paid directly to the Copyright Clearance Center (CCC), 222 Rosewood Drive, Danvers, MA 01923. Payment may also be made electronically through CCC Online at copyright.com. Other copying for republication, resale, advertising or promotion, or any form of systematic or multiple reproduction of any material in this book is prohibited except with permission in writing from the publisher. The CCC fee code is 0277-786X/16/\$18.00.

Printed in the United States of America.

Publication of record for individual papers is online in the SPIE Digital Library.

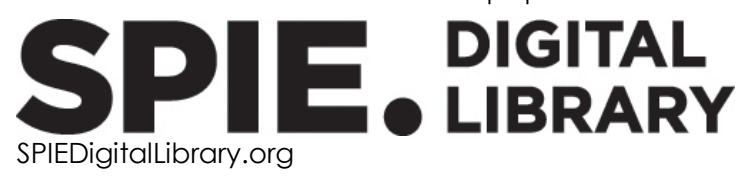

Paper Numbering: Proceedings of SPIE follow an e-First publication model. A unique citation identifier (CID) number is assigned to each article at the time of publication. Utilization of CIDs allows articles to be fully citable as soon as they are published online, and connects the same identifier to all online and print versions of the publication. SPIE uses a six-digit CID article numbering system structured as follows:

- The first four digits correspond to the SPIE volume number.

- The last two digits indicate publication order within the volume using a Base 36 numbering

system employing both numerals and letters. These two-number sets start with 00, 01, 02, 03, 04, 05, 06, 07, 08, 09, OA, OB ... 0Z, followed by 10-1Z, 20-2Z, etc. The CID Number appears on each page of the manuscript. 


\title{
Contents
}

\author{
$\checkmark$ Authors \\ vii Conference Committee
}

\section{SUPER RESOLUTION MICROSCOPY}

992505 Study of biological reaction in cancer cell with spectroscopic imaging ellipsometry [9925-4]

992506 Photoacoustic tomography of unlabelled red blood cell at the nanoscale [9925-6]

TIP-ENHANCED RAMAN SPECTROSCOPY/MICROSCOPY

992509 High-efficiency and high-resolution apertureless plasmonic near-field probe under internal illumination [9925-9]

9925 OA TERS at work: 2D materials, from graphene to 2D semiconductors [9925-10]

NEAR-FIELD SPECTROSCOPY/MICROSCOPY

9925 OG Multichannel near-field nanoscopy of circular and linear dichroism at the solid-state [9925-17]

PLASMONICS FOR NANOSPECTROSCOPY II

$99250 \mathrm{~J}$ Sub-one-nanometer gap (SONG) for nanogap-enhanced Raman scattering (NERS) (Invited Paper) [9925-20]

$9925 \mathrm{OL} \quad$ Surface phonon coupling within boron nitride resolved by a novel near-field infrared pump-probe imaging technique [9925-22]

9925 ON Electron energy-loss spectroscopy of coupled plasmonic systems: beyond the standard electron perspective [9925-24]

\section{NANOSPECTROSCOPY}

992500 3D SERS imaging based on chemically-synthesized highly-symmetric nanoporous silver microparticles (Invited Paper) [9925-25]

$99250 Q \quad$ Tip-enhanced Raman spectroscopy of nanostructures on epitaxial graphene and graphene microisland [9925-27] 
Proc. of SPIE Vol. $9925992501-4$

Downloaded From: https://www.spiedigitallibrary.org/conference-proceedings-of-spie on 26 Apr 2023 Terms of Use: https://www.spiedigitallibrary.org/terms-of-use 


\section{Authors}

Numbers in the index correspond to the last two digits of the six-digit citation identifier (CID) article numbering system used in Proceedings of SPIE. The first four digits reflect the volume number. Base 36 numbering is employed for the last two digits and indicates the order of articles within the volume. Numbers start with 00, 01, 02, 03, 04, 05, 06, 07, 08, 09, 0A, 0B...0Z, followed by 10-1Z, 20-2Z, etc.

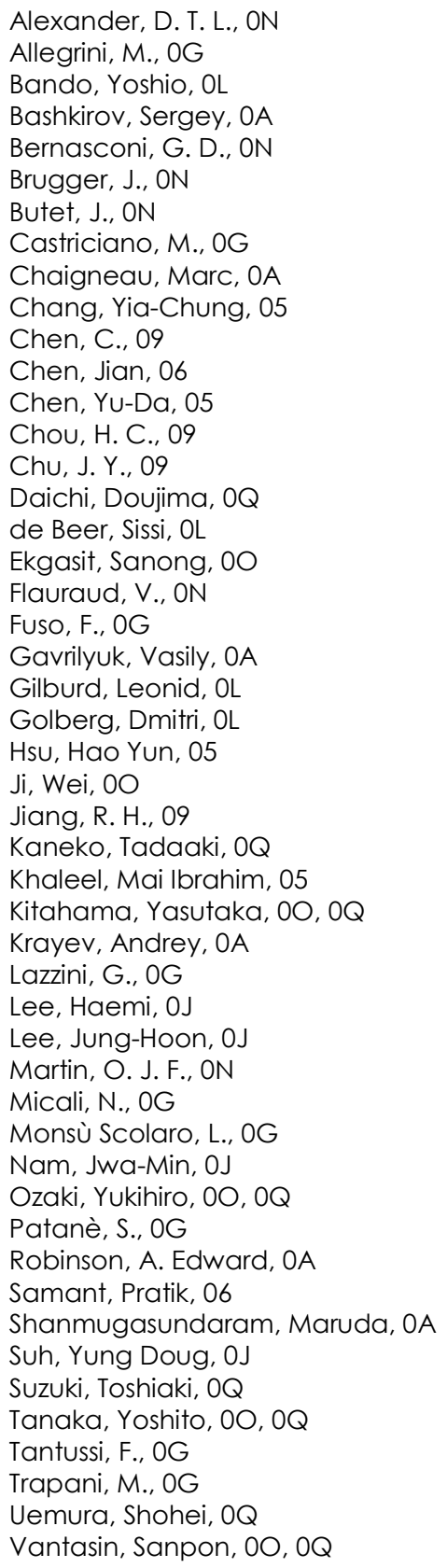


Proc. of SPIE Vol. $9925992501-6$

Downloaded From: https://www.spiedigitallibrary.org/conference-proceedings-of-spie on 26 Apr 2023 Terms of Use: https://www.spiedigitallibrary.org/terms-of-use 


\section{Conference Committee}

Symposium Chairs

Harry A. Atwater, Jr., California Institute of Technology (United States)

Nikolay I. Zheludev, Optoelectronics Research Centre

(United Kingdom) and Nanyang Technological University

(Singapore)

Symposium Co-chairs

David L. Andrews, University of East Anglia (United Kingdom)

James G. Grote, Air Force Research Laboratory (United States)

Conference Chairs

Prabhat Verma, Osaka University (Japan)

Alexander Egner, Laser-Laboratorium Göttingen e.V. (Germany)

Conference Program Committee

Balpreet Singh Ahluwalia, University of Tromsø (Norway)

Joerg Bewersdorf, Yale School of Medicine (United States)

Alberto Diaspro, Istituto Italiano di Tecnologia (Italy)

Christian Eggeling, University of Oxford (United Kingdom)

Joerg Enderlein, Georg-August-Universität Göttingen (Germany)

Katsumasa Fujita, Osaka University (Japan)

Stefan W. Hell, Max-Planck-Institut für Biophysikalische Chemie

(Germany)

Samuel Hess, University of Maine (United States)

Bo Huang, University of California, San Francisco (United States)

Satoshi Kawata, Osaka University (Japan)

Thomas A. Klar, Johannes Kepler Universität Linz (Austria)

Alfred J. Meixner, Eberhard Karls Universität Tübingen (Germany)

Peter Nordlander, Rice University (United States)

Bruno Pettinger, Fritz-Haber-Institut der Max-Planck-Gesellschaft (Germany)

Markus B. Raschke, University of Colorado Boulder (United States)

Bin Ren, Xiamen University (China)

Vahid Sandoghdar, Max-Planck-Institut für die Physik des Lichts

(Germany)

Markus Sauer, Julius-Maximilians-Universität Würzburg (Germany)

Yung Doug Suh, Korea Research Institute of Chemical Technology (Korea, Republic of) 
Din Ping Tsai, National Taiwan University (Taiwan)

Renato Zenobi, ETH Zürich (Switzerland)

Xiaowei Zhuang, Harvard University (United States)

\section{Session Chairs}

1 Super Resolution Microscopy

Prabhat Verma, Osaka University (Japan)

2 Tip-enhanced Raman Spectroscopy/Microscopy

Remo Proietti Zaccaria, Istituto Italiano di Tecnologia (Japan)

3 Plasmonics for Nanospectroscopy I

Nicholas J. Borys, The Molecular Foundry (United States)

4 Near-field Spectroscopy/Microscopy

Natalia Martín Sabanés, Max-Planck-Institut für Polymerforschung (Germany)

5 Plasmonics for Nanospectroscopy II

Alexander Egner, Laser- Laboratorium Göttingen e.V. (Germany)

6 Nanospectroscopy

Haemi Lee, Korea Research Institute of Chemical Technology

(Korea, Republic of) 